\title{
$B R C A 1$ c.2845insA is a recurring mutation with a founder effect in Singapore Malay women with early onset breast/ovarian cancer
}

\author{
J-H Sng, A B Ali, S C Lee, D Zahar, J E L Wong, V Blake, A Sharif, G Cross, P T C lau
}

J Med Genet 2003;40:e1 17 (http://www.jmedgenet.com/cgi/content/full/40/10/e1 17)

B reast cancer is the third most common form of cancer worldwide, after lung and stomach cancer, and is the most common cause of cancer death in women. ${ }^{1}$ The age-adjusted incidence rates of breast cancer are $176 \%$ higher in developed than developing countries. ${ }^{2}$ In Singapore, breast cancer is the most common cancer in women and the incidence rate in 1993-1997 was 2.3 times higher than in 1968-1972, with an annual increase significantly higher in pre-menopausal than post-menopausal women $(5.7 \% \quad v$ $3.9 \%) .^{3-4}$ Of note, the Malay ethnic group in Singapore has shown the greatest increase in the incidence of breast cancer $(4.4 \%)$ over the past three decades compared with the Chinese and Indian subpopulations. In addition, breast cancer in Malay women has shown a bimodal distribution in age specific incidence, at 45 and 65 years, and a strong birth cohort effect has been noticed in this group.

The majority of breast cancer is sporadic, but about $5 \%$ to $10 \%$ of all breast and ovarian cancer cases are believed to be attributable to the inheritance of germline mutations in high penetrance, autosomal dominant susceptibility genes. ${ }^{5-7}$ The identification and cloning of one such gene BRCAl (OMIM \# $113705)^{8-9}$ has rapidly led to the characterisation of mutations in this gene among high risk families, as well as early onset breast and/or ovarian cancer patients or tumour series in populations worldwide. ${ }^{10-14}$ Several founder and recurrent mutations have now been identified in specific ethnic groups, such as African-Americans, Ashkenazi Jews, Dutch, Finns, French-Canadians, Icelanders, Japanese, Norwegians, Swedes, and Russians, among others. ${ }^{15-17}$ However, almost all molecular studies of BRCAI performed have defined breast cancer risks and related genetic factors in Caucasian women of European descent, and studies in Asian populations, although on the increase, have been few. ${ }^{18-24}$ Among these Asian populations, recurrent and founder mutations have now been reported for Japanese, Filipinos, Thais, and Chinese. ${ }^{18} 22$ 24-25

Given the increase in the incidence of breast cancer, together with the rise in the number of patients presenting with early onset breast cancer among Singapore Malays, we decided to characterise germline BRCAI mutations and polymorphic variants in patients presenting with early onset breast or ovarian cancer, with or without a family history, in order to evaluate the proportion of cancers attributable to mutations in this gene.

\section{MATERIALS AND METHODS}

\section{Study patients and determination of family history}

From 2001 to 2002, 62 consecutive unrelated Malay patients presenting to the National University Hospital were eligible for BRCAl testing if they had a diagnosis of breast or ovarian cancer before the age of 45 and 50 years respectively. This study had institutional ethics committee approval, and signed written informed consent was obtained from each participant before blood collection. The family histories on number and age of relatives, numbers of affected relatives,

\section{Key points}

- Breast cancer is the third most common form of cancer worldwide, after lung and stomach cancer, and is the most common cause of cancer death in women.

- Most studies have been carried out in women of European descent, and as yet, few Asian studies have been published.

- We characterised germline BRCAl mutations and polymorphic variants in 62 unrelated Singapore Malay patients presenting with early onset breast or ovarian cancer, with or without a family history, in order to evaluate the proportion of cancers attributable to mutations in this gene.

- Ten distinct BRCAl sequence alterations were identified in 12 patients. One, the frameshift mutation c. 2845 ins A, which produces a truncated protein signal at codon 914, was found to occur in six apparently unrelated patients, but was not found in 114 unaffected females (matched on basis of ethnicity and age) with no family history of cancer.

- Haplotype analysis of all six patients with the recurrent c. 2845ins A mutation showed a shared haplotype for all three intragenic polymorphic markers, strongly suggesting the presence of a founder effect at this locus.

- If this gene is indeed a founder effect, it may open the possibility of widescale gene screening for Singapore Malays.

and age of onset of cancers were determined by direct interview. To determine the frequency in the general Malay population of the recurring genetic variant detected in the study group, blood samples were collected from 114 unrelated normal subjects randomly selected from the general population. This control set was matched to the cases on basis of race, gender, and 5 year age intervals.

\section{Molecular studies}

DNA isolation

Peripheral blood lymphocytes were isolated from blood samples using Ficoll-Paque according to the manufacturer's instructions (Pharmacia Biotech, Uppsala, Sweden). Total genomic DNA was extracted from the lymphocytes using standard procedures. ${ }^{26}$

Abbreviations: $\mathrm{BIC}$, Breast Cancer Information Core; PCR, polymerase chain reaction; PTT, protein transcription-translation analysis; SSCP, single strand conformational polymorphism 


\section{Mutation analysis of $B R C A 1$}

The entire coding sequence, splice junctions and neighbouring intronic regions of BRCAl were screened using a combination of methods, primarily single strand conformational polymorphism (SSCP) analysis and the protein truncation test. SSCP analysis, using primer pairs spanning the BRCAl coding region ${ }^{14}$ including the intron-exon boundaries, was performed for all coding exons except for exon 11 . Polymerase chain reaction (PCR) amplif ication of genomic DNA was carried out in $10 \mu \mathrm{l}$ volumes containing $50 \mathrm{ng}$ of genomic DNA, $1.5 \mathrm{mmol} / \mathrm{l} \mathrm{MgCl} 2,50 \mathrm{mmol} / \mathrm{l} \mathrm{KCl}, 10 \mathrm{mmol} / \mathrm{l}$ Tris-HCl (pH 8.3), $200 \mu \mathrm{mol} / \mathrm{l}$ dNTPs (Promega, Madison, WI, USA), $0.8 \mu \mathrm{mol} / \mathrm{l}$ of each primer and $0.75 \mathrm{U}$ of Taq polymerase (Promega). An initial denaturation step at $94^{\circ} \mathrm{C}$ for 3 min was followed by 35 cycles of amplification (30 s at $94^{\circ} \mathrm{C}, 1 \mathrm{~min}$ at the respective annealing temperature, and $1 \mathrm{~min}$ at $72^{\circ} \mathrm{C}$ ), and a final extension at $72^{\circ} \mathrm{C}$ for $5 \mathrm{~min}$ in a thermal cycler (GeneAmp ${ }^{\circledR}$ PCR System 9700; PE Applied Biosystems, Foster City, CA, USA). A $1.2 \mu$ laliquot of the PCR product was diluted into $4.9 \mu \mathrm{l}$ of denaturing loading buffer (95\% formamide, $10 \mathrm{mmol} / \mathrm{l} \mathrm{NaOH}, 0.05 \%$ xylene cyanol FF and $0.05 \%$ bromophenol blue), heated at $94^{\circ} \mathrm{C}$ for $5 \mathrm{~min}$, and loaded for electrophoresis. SSCP gels consisting of $0.5 \times$ mutation detection enhancement solution (FMC Bioproducts, Rockland, ME, USA) in $0.6 \times$ TBE buffer at $4 \mathrm{~W}$ for $18-22 \mathrm{~h}$ at $4^{\circ} \mathrm{C}$. After electrophoresis, the SSCP bands were visualised by silver staining and the DNA bands of variant mobility were excised from the gels and eluted into $50 \mu \mathrm{l}$ TE ( $\mathrm{pH} 8.0)$. The eluted DNA (10 $\mu \mathrm{l})$ was used as a template for reamplification and the DNA product was sequenced.

Protein transcription-translation (PTT) analysis was used to detect truncating mutations in exon $11 .{ }^{27}{ }^{28}$ Exon 11 was amplified in three overlapping fragments, ranging in size from 1275 to $1600 \mathrm{bp}$. PCR products were purified, and the mRNA was translated into radiolabelled peptides using the $\mathrm{TnT}^{\mathrm{TM}}$ T7 Quick System (Promega). $\left[{ }^{35} \mathrm{~S}\right]$-methionine/ cysteine (NEN Research Products, Boston, MA, USA) was used for radioactive labelling of the translation products. The products were size separated on $12 \%$ SDS-PAGE gels. After electrophoreses, the gels were dried and autoradiographed on Hyperfilm $^{\mathrm{TM}}$ (Amersham Biosciences, Amersham, Bucks, UK) overnight at $-70^{\circ} \mathrm{C}$.

\section{DNA sequencing}

All PCR products showing an electrophoretic variant pattern by SSCP or PTT were reamplified from the original genomic DNA, and both strands were directly sequenced by the fluorometric method with automated sequencing procedures according to the manufacturers' instructions. All the deleterious mutations and genetic variants were named according to the practice of the BIC database, with the nucleotide numbering starting at the first transcribed base of $B R C A l$ according to GenBank entry U14680. ${ }^{29}$ All insertions or deletions were designated according to HUGO recommendations. ${ }^{30}$

\section{Analysis of recurrent mutation}

We screened 114 unaffected females (matched on basis of ethnicity and age) with no family history of cancer for the presence of the recurring mutation found in the patients. The region of exon 11, which contains the recurring mutation, was amplified from the genomic DNA and the subsequent PCR products were analysed by SSCP.

\section{Haplotype analysis}

The disease associated haplotypes in all the patients with the recurrent mutation and 76 controls were constructed by genotyping three intragenic BRCAl microsatellite markers: D17S855, D17S1322, and D17S1323. The primer sequences for the amplification of the markers were obtained from Anderson et $a l^{31}$ and Neuhausen et al. ${ }^{32}$ The fluorescently labelled PCR products were electrophoresed on an Automatic Laser Fluorescent Express machine (Amersham Biosciences) with a fluorescence labelled DNA fragment size standard.

\section{RESULTS}

The study involves the molecular analysis of the BRCAl gene in 62 consecutive Malay patients affected with early onset breast and/or ovarian cancer, with/without family history. Table I summarises the characteristics of the incident cases from the Surgery and Oncology clinics of the National University Hospital, Singapore. The mean age of diagnosis was 38.6 years (range 25-45 years) and 41.8 years (range 19-50 years) for breast cancer and ovarian cancer cases respectively. Fifty patients were early onset breast or ovarian cases with no family history of these cancers, while the remaining twelve patients had affected relatives with either breast or ovarian cancer. Of these twelve patients, nine presented with breast cancer under the age of 45 years and three with ovarian cancer under the age of 50 years.

\section{Characterisation of alterations in BRCA 1 sequence}

In the 62 patients with early onset breast or ovarian cancer under the ages of 45 and 50 years respectively, 10 distinct BRCAI sequence alterations were identified (table 2) in 12 patients. These alterations comprised one disease causing mutation, two missense changes, three neutral polymorphisms, and four intronic variants. Of these, one missense mutation and three of the intronic variants were novel mutations that have not yet been reported in the Breast Cancer Information Core (BIC) database. ${ }^{14}$

\section{$B R C A 1$ mutation causing disease}

The frameshift mutation BRCAl c.2845insA, which produces a truncated protein signal at codon 914, was found to occur in six apparently unrelated patients. Four of the six cases (patients N536, N587, N610, N521; 66.7\%) had at least a first or second degree relative with breast or ovarian cancer (table 2). Three patients (N536, N587, N610) were early onset breast cancer patients with a positive family history of breast/ ovarian cancer (among first and second degree relatives), while the other three (N521, N576, N590) were ovarian cancer patients, of whom only one (N521) reported a family history of breast carcinoma among first and third degree relatives. The breast cancer patients, N536 and N587, and the ovarian cancer patient N521 showed a predominance of breast cancer in their families. Patient N610 was diagnosed with breast cancer at the age of 35 years, while her mother had ovarian cancer at the age of 49 years. Two ovarian cancer patients, N576 and N590, had no reported family history of breast/ovarian cancer. This particular exon 11 mutation was first reported in a retrospective study of apparently sporadic breast cancer patients (BIC database) and subsequently described in another study where it was found in two of seven unrelated subjects of Malay ethnicity. ${ }^{33}$ In addition, our study also showed that none of the 114 unaffected controls were found to carry this mutation.

The genotypes of the six unrelated affected patients with the c.2845insA mutation were examined at three BRCAI intragenic markers. There were no available relatives to establish linkage phase, but for each of the loci, one allele was present in all six mutation carriers. For D17S1323 and D17S855, this allele was also common in the control individuals, but for D17S1322, this allele was only found twice in 152 chromosomes (1.3\%). These data are consistent with all the c.2845insA mutation being located on a chromosome with a common haplotype, supporting an ancestral link (table 3). In addition, of the 76 controls 
Table 1 Clinical and pathologic characteristics of early onset breast and ovarian cancer cases in Singapore Malay patients studied retrospectively

\begin{tabular}{|c|c|c|c|}
\hline Characteristics & Cases $(\%)$ & $\begin{array}{l}\text { No. with } \\
\text { BRCA I } \\
\text { sequence } \\
\text { alterations } \dagger \\
(\%)\end{array}$ & $\begin{array}{l}\text { No. with } \\
\text { the BRCA1 } \\
2841 / \\
5 \text { insA } \\
\text { mutation } \\
\text { (\%) }\end{array}$ \\
\hline $\begin{array}{l}\text { Total number (breast and } \\
\text { ovarian) } \ddagger\end{array}$ & 62 & $12(19.4)$ & $6(9.7)$ \\
\hline $\begin{array}{l}\text { Breast cancer cases§ } \\
\text { Age of onset (years) }\end{array}$ & 50 & 9 & 3 \\
\hline$<35$ & $11(22.0)$ & $3(33.3)$ & - \\
\hline $35-44$ & $39(78.0)$ & $6(66.7)$ & $3(100)$ \\
\hline \multicolumn{4}{|c|}{ Family history (first, second, or third degree relatives) } \\
\hline $\begin{array}{l}\text { Breast cancer (diagnosis at any } \\
\text { age) }\end{array}$ & $8(16.0)$ & $2(22.2)$ & $2(66.7)$ \\
\hline $\begin{array}{l}\text { Breast cancer (diagnosis }<51 \\
\text { years) }\end{array}$ & $5(10.0)$ & $1(11.1)$ & $1(33.3)$ \\
\hline Breast cancer $(>1)$ & $1(2.0)$ & $1(11.1)$ & $1(33.3)$ \\
\hline Ovarian cancer & $1(2.0)$ & $1(11.1)$ & $1(33.3)$ \\
\hline Other types of cancer & $10(20.0)$ & $4(44.4)$ & $2(66.7)$ \\
\hline \multicolumn{4}{|l|}{ Tumour histology } \\
\hline Infiltrating ductal carcinoma & $30(60.0)$ & $7(77.8)$ & $3(100.0)$ \\
\hline Infiltrating lobular carcinoma & $2(4.0)$ & $1(11.1)$ & - \\
\hline Mucinous & $3(6.0)$ & - & - \\
\hline Other & $11(22.0)$ & $1(11.1)$ & - \\
\hline Unknown & $4(8.0)$ & - & - \\
\hline \multicolumn{4}{|l|}{ Nuclear grade } \\
\hline 1 & $2(4.0)$ & - & - \\
\hline 2 & $4(8.0)$ & - & - \\
\hline 3 & $33(66.0)$ & $5(55.6)$ & $1(33.3)$ \\
\hline Unknown & $11(22.0)$ & $4(44.4)$ & $2(66.7)$ \\
\hline \multicolumn{4}{|c|}{ Presence of lymph node involvement } \\
\hline Yes & $20(40.0)$ & $3(33.3)$ & - \\
\hline No & $17(34.0)$ & $3(33.3)$ & 1 (33.3) \\
\hline Unknown & $13(26.0)$ & $3(33.3)$ & $2(66.7)$ \\
\hline \multicolumn{4}{|l|}{ Oestrogen receptor } \\
\hline Positive & $17(34.0)$ & $2(22.2)$ & - \\
\hline Negative & $19(38.0)$ & $5(55.6)$ & $2(66.7)$ \\
\hline Unknownt† & $14(28.0)$ & $2(22.2)$ & $1(33.3)$ \\
\hline \multicolumn{4}{|l|}{ Progesterone receptor } \\
\hline Positive & $23(46.0)$ & $3(33.3)$ & - \\
\hline Negative & $12(24.0)$ & $4(44.4)$ & $2(66.7)$ \\
\hline Unknownt† & $15(30.0)$ & $2(22.2)$ & $1(33.3)$ \\
\hline $\begin{array}{l}\text { Ovarian cancer cases (age of } \\
\text { onset }<50 \text { years) } \ddagger \ddagger\end{array}$ & 12 & 3 & 3 \\
\hline \multicolumn{4}{|c|}{ Family history (first, second, or third degree relatives) } \\
\hline $\begin{array}{l}\text { Breast cancer (diagnosis }<51 \\
\text { years) }\end{array}$ & $3(25.0)$ & $1(33.3)$ & $1(33.3)$ \\
\hline Breast cancer $(>1)$ & $2(16.7)$ & $1(33.3)$ & $1(33.3)$ \\
\hline Other types of cancer & $3(25.0)$ & 1 (33.3) & 1 (33.3) \\
\hline
\end{tabular}

tSequence alterations include frameshift and missense mutations; polymorphisms and intronic variants.

$\ddagger$ ¿ased on total number of early onset breast cancer and ovarian cancer cases with/without family history.

§Based on total number of incident breast cancer cases.

-Percentages were calculated from cases in which the lymph node involvement status and receptor status were examined.

t†lnclusive of ductal carcinoma in situ cases which are not routinely assessed for oestrogen/progesterone receptor status.

$\ddagger \ddagger$ Based on total number of incident ovarian cancer cases.

haplotyped, none shared the same haplotype as the six positive samples, which leads us to infer that there may be a specific subpopulation within the Malay population in which this mutation occurs.

\section{Missense mutations of unknown significance}

Two missense mutations of unknown significance were detected. The first, c.335C $\rightarrow \mathrm{A} \quad(\mathrm{S} 72 \mathrm{R})$ is not a common mutation, having only been described once before in the BIC database. This amino acid change is located within the BRCAl RING finger structural domain, in close proximity of a RING finger motif. The other mutation, c. $778 \mathrm{C} \rightarrow \mathrm{A}(\mathrm{S} 220 \mathrm{Y})$ is novel, and was found in patient N536, who also harbours the recurring frameshift mutation c.2845insT.
Common polymorphisms and intronic variants

Three neutral polymorphisms were detected in this study. Two patients harboured the single base substitution, c. $233 \mathrm{G} \rightarrow \mathrm{A}$, and two other breast cancer patients, N599 and N616, had the same two intronic polymorphisms, IVS16$68 \mathrm{~A} \rightarrow \mathrm{G}$ and IVS16-92A $\rightarrow \mathrm{G}$. These three polymorphisms have been reported previously in the BIC database, and they are among the top 20 mutation frequencies that have been described by designation. The remaining four intronic variants were IVS6+26CA $\rightarrow$ AC, IVS5-44G $\rightarrow$ A, IVS7-34T $\rightarrow$ C, and IVS18+72G $\rightarrow$ C, three of which are single-base substitutions, are novel and have never been reported. The intronic variant IVS18+72G $\rightarrow \mathrm{C}$ was detected in a breast cancer patient, N587, who not only had the recurring mutation but also a family history of breast cancer (mother and maternal aunt).

\section{DISCUSSION}

The discovery of the BRCA genes has led to major advancements in our understanding of breast cancer carcinogenesis, both in hereditary and sporadic breast cancers. However, the primary clinical application of this new knowledge to date has been the identification of high risk individuals. Data from large, multicancer families have shown that $55-80 \%$ of carriers of a germline mutation at the BRCA gene develop breast cancer by the age of 70 years, with a similar level of risk of ovarian cancer. ${ }^{34-36}$ Weaker associations have also been found between BRCA mutations and pancreatic, prostatic, and colonic cancers. ${ }^{37-40}$

Widespread BRCA gene testing has unfortunately not been practical, partially owing to the low estimated prevalence in the general population, accounting for less than 5\% of all breast cancer in outbred populations. ${ }^{41}$ In addition, mutation screening to date has been difficult and costly because of the size and complexity of the BRCA genes. With the exception of some genetically isolated populations, deleterious mutations at the BRCA loci have been shown to occur across the entire length of the genes, requiring full-length analysis for a comprehensive screen.

Earlier studies carried out in the Singapore population by our group and others have shown a similar prevalence of $B R C A 1$ mutations to those in reports from western series. ${ }^{20} 33$ Interestingly, one common finding was that the same BRCAl deleterious mutation 2845insA was found in 2/7 Malay patients in one study, suggesting the presence of a founder mutation. ${ }^{33}$ Follow on studies confirming such a possibility, combined with the low incidence of mutations elsewhere in the gene, would have more significant clinical applications, as a simplified mutation test limited to specific regions of the gene would allow for more widespread gene testing and a more accurate estimate of mutation penetrance outside of multiple cancer families.

To test the above hypothesis, we studied the spectrum of BRCA1 mutations in 62 Singapore Malay patients with early onset breast/ovarian cancer. All cases had their treatment at the same hospital, allowing for histological confirmation. The histolological phenotypes of mutation carriers were in keeping with previously published series, with a propensity for BRCAl related tumours to be of high grade, of no special type, and oestrogen receptor negative. The prevalence of BRCA1 mutation in Southeast Asian breast and ovarian cancer patients, in particular of Malay ethnicity, has not been adequately reported and our study constitutes the largest cohort of such Malay patients to date. In this study, the prevalence of BRCAl mutation carriers in Malays was found to be similar to that of outbred populations, and despite a full analysis of the entire coding region and adjacent intronic segments, all the deleterious mutations were found to be c.2845insA. In addition, none of the controls was found to 
Table 2 BRCA 1 sequence alterations in Singapore Malay patients with early onset breast/ovarian cancer

\begin{tabular}{|c|c|c|c|c|c|c|}
\hline \multirow[b]{2}{*}{ Case } & \multirow[b]{2}{*}{ Exon } & \multirow{2}{*}{$\begin{array}{l}\text { Sequence } \\
\text { alteration }\end{array}$} & \multirow{2}{*}{$\begin{array}{l}\text { Amino acid } \\
\text { change }\end{array}$} & \multirow{2}{*}{$\begin{array}{l}\text { Age } \\
\text { (years) }\end{array}$} & \multicolumn{2}{|l|}{ Family history } \\
\hline & & & & & Breast /ovarian cancer & Other cancers \\
\hline \multicolumn{7}{|c|}{$\begin{array}{l}\text { BRCA 1 sequence variants } \\
\text { Frameshift mutation }\end{array}$} \\
\hline N536 (Br) & 11 & c. $2845 \mathrm{ins} A$ & $\mathrm{~N} 909 \mathrm{fs}_{\mathrm{s}} \times 5$ & 35 & $\mathrm{Br} 33$ (S) & Co58 (F) \\
\hline N587 (Br) & 11 & c. 2845 ins $A$ & N909fsX5 & 44 & $\mathrm{Br60}(\mathrm{M}), \mathrm{Br} 50$ (MA) & Nil \\
\hline $\mathrm{N} 610(\mathrm{Br})$ & 11 & c. 2845 ins $A$ & N909fsX5 & 35 & Ov49 (M) & CSU (MA) \\
\hline N521(Ov) & 11 & c. 2845 ins $A$ & N909fsX5 & 49 & $\begin{array}{l}\mathrm{Br} 37(\mathrm{~S}), \mathrm{Br} 30(\mathrm{MA}) \\
\mathrm{Br} 40(\mathrm{MC})\end{array}$ & Nil \\
\hline N576 (Ov) & 11 & c. 2845 ins $A$ & N909fs X5 & 50 & Nil & Nil \\
\hline N590 (Ov) & 11 & c. 2845 ins $A$ & $\mathrm{~N} 909 \mathrm{fs}_{\mathrm{s}} \mathrm{X} 5$ & 40 & Nil & St (MA) \\
\hline \multicolumn{7}{|c|}{ Missense mutations } \\
\hline N591 (Br) & 6 & c. $335 \mathrm{C} \rightarrow \mathrm{A}$ & $\mathrm{S} 72 \mathrm{R}$ & 41 & $\mathrm{Nil}$ & Nil \\
\hline N536 (Br) & 10 & c. $778 \mathrm{C} \rightarrow \mathrm{A}$ & S220Y & 35 & $\mathrm{Br33}$ (S) & $\operatorname{Co59}(F)$ \\
\hline \multicolumn{7}{|c|}{ Neutral polymorphisms } \\
\hline $\mathrm{N} 33(\mathrm{Br})$ & 3 & $233 G \rightarrow A$ & K38K & 38 & Nil & Nil \\
\hline N522 (Br) & 3 & $233 G \rightarrow A$ & K38K & 32 & Nil & Nil \\
\hline N599 (Br) & 17 & c. $5106-68 \mathrm{~A} \rightarrow \mathrm{G}$ & IVS16-68A $\rightarrow \mathrm{G}$ & 29 & Nil & Co70 (MGF) \\
\hline N616 (Br) & 17 & c. $5106-68 A \rightarrow G$ & IVS16-68A $\rightarrow \mathrm{G}$ & 35 & Nil & - \\
\hline N599 (Br) & 17 & c. $5106-92 \mathrm{~A} \rightarrow \mathrm{G}$ & IVS16-92A $\rightarrow G$ & 29 & Nil & Co70 (MGF) \\
\hline N616 (Br) & 17 & c. $5106-92 A \rightarrow G$ & IVS16-92A $\rightarrow G$ & 35 & Nil & Nil \\
\hline \multicolumn{7}{|c|}{ Intronic variants } \\
\hline N591 (Br) & 6 & c. $420+26 C A \rightarrow A C$ & IVS6+26CA $\rightarrow$ AC & 41 & Nil & Nil \\
\hline N591 (Br) & 6 & c. $432-44 \mathrm{G} \rightarrow \mathrm{A}$ & IVS5-44G $\rightarrow \mathrm{A}$ & 41 & Nil & Nil \\
\hline $\mathrm{N} 511$ (Br) & 8 & c. $561-34 \mathrm{~T} \rightarrow \mathrm{C}$ & IVS7-34T $\rightarrow$ C & 34 & Nil & Brn53 (F) \\
\hline N587 (Br) & 18 & c. $5272+72 \mathrm{G} \rightarrow \mathrm{C}$ & IVS18+72G $\rightarrow C$ & 44 & $\mathrm{Br60}(\mathrm{M}), \mathrm{Br} 50$ (MA) & Nil \\
\hline
\end{tabular}

carry this mutation. To the best of our knowledge, all reported BRCAl mutations in Malays have been shown to occur at this position, with the exception of the c.5448insC mutation, which was reported in a Malay woman diagnosed with breast cancer at the age of 32 years with no significant family history of the disease. ${ }^{42}$ Haplotype analysis of all six patients with the recurrent c.2845insA mutation showed a shared haplotype for all three intragenic polymorphic markers, strongly suggesting the presence of a founder effect at this locus. Interestingly, this haplotype was not seen in 76 controls, indicating that this may be a specific haplotype existing within a specific subpopulation of the Malays, and that this haplotype is associated with increased susceptibility to breast/ovarian cancer. However, more controls will have to be investigated in order to assess the prevalence of this haplotype. Case tracing of family members in the families that harbour the common mutation is presently underway to assess the segregation of this haplotype to the affected members.

Although BRCAl mutations have largely been reported to occur throughout the gene, recurrent mutations have now been identified in specific subpopulations. This phenomenon is most likely to occur in populations that have historically been geographically or politically isolated from surrounding populations, and in which reproduction occurs almost solely

Table 3 Genotypes for the recurrent BRCA 1 c.2845insA mutation identified in the Malay subjects

\begin{tabular}{lllllll}
\hline & \multicolumn{2}{l}{$\begin{array}{l}\text { Intron 12 } \\
\text { D17S1323 }\end{array}$} & \multicolumn{2}{l}{$\begin{array}{l}\text { Intron 19 } \\
\text { D17S1322 }\end{array}$} & \multicolumn{2}{l}{$\begin{array}{l}\text { Intron 20 } \\
\text { D17S855 }\end{array}$} \\
\hline N536 (Br) & 155 & 159 & 119 & 127 & 142 & 148 \\
N587 (Br) & 157 & 159 & 115 & 127 & 142 & 142 \\
N610 (Br) & 153 & 159 & 119 & 127 & 142 & 146 \\
N521(Ov) & 153 & 159 & 119 & 127 & 142 & 146 \\
N576 (Ov) & 157 & 159 & 121 & 127 & 142 & 144 \\
N590 (Ov) & 153 & 159 & 125 & 127 & 142 & 148 \\
\hline
\end{tabular}

Common haplotypes are shown in bold. within the group, such as the presentday Singapore Malays. This ethnic group is part of a race of people inhabiting what is today peninsular Malaysia and portions of adjacent islands in southeast Asia, including the east coast of Sumatra, the coast of Borneo, and the smaller islands that lie between these areas, including Singapore. The Singapore Malays are typically characterised by their ethnically homogenous structure and low propensity towards immigration. In addition, the absence of the carrier haplotype among the 76 controls in our study also raises the possibility of a distinct sub-group at increased risk among the Malays. A similar situation has also been seen in other genetically isolated populations such as in Finland and Iceland, where mutation at the c.999del5 site of the BRCA2 gene accounts for almost all mutations in both BRCA genes. ${ }^{43-45}$

The discovery of founder mutations has significant clinical applications, as a directed search for such mutations is likely to account for the majority of carriers in the population. Further studies will be necessary to estimate more accurately the population frequency of this mutation. The simplification of the mutation screening process will allow for more widespread gene testing outside of hereditary breast and/or ovarian cancer syndromes, which are rare in the general population. In addition, the identification of carriers outside of these families will also allow for a more accurate assessment of the penetrance of BRCA mutations, a vital requirement for genetic counselling and clinical decision making regarding intervention, with either closer surveillance or prophylactic surgery.

Nevertheless, the risk estimates among mutation carriers is still likely to fall within wide confidence intervals. In carriers of the Ashkenazi Jewish founder mutations, a wide heterogeneity of risk for both breast and ovarian cancers has been reported, possibly as a result of interaction with genetic or environmental modifiers, as indeed is also the case with the BRCA2 999del5 Icelandic founder mutation, which has been reported to have increased penetrance across successive generations. Whether such modifiers are found in Malay carriers will be an area of future research. 


\section{ACKNOWLEDGEMENTS}

We wish to thank the patients and normal subjects for their participation. This study was supported by a research grant from the National Healthcare Group, Singapore; Contract grant number: NHG$\mathrm{RPR} / 01108$

\section{Authors' affiliations}

J-H Sng, A B Ali, D Zahar, Department of Surgery, Faculty of Medicine, National University of Singapore, 10 Kent Ridge Crescent, Singapore 119260

S C Lee, J E L Wong, Department of Medical Oncology, National University Hospital, 5 Lower Kent Ridge Road, Singapore 119074 V Blake, A Sharif, G Cross, Centre for Medical Genetics, City Hospital, Nottingham NG5 1PB, UK

P T C lau, Department of Surgery, National University Hospital, Singapore

Correspondence to: Dr Jen-Hwei Sng, Department of Surgery, Faculty of Medicine, National University of Singapore, 10 Kent Ridge Crescent, Singapore 119260; sursngjh@nus.edu.sg

\section{REFERENCES}

1 Parkin DM, Pisani P, Ferlay J. Estimates of the worldwide incidence of 25 major cancers in 1990. Int J Cancer 1990;80:827-41.

2 Parkin DM. The global burden of cancer. Cancer Biol 1998;8:219-35.

3 Seow A, Duffy SW, McGee MA, Lee J, Lee HP. Breast cancer in Singapore: trends in incidence 1968-1992. Int J Epidemiol 1996:25:40-5.

4 Chia KS, Seow A, Lee HP, Shanamgaratnam K. Cancer incidence in Singapore 1993-1997. Singapore cancer registry report 2000, No. 5.

5 Lynch HT, Albano WA, Danes BS, Layłon MA, Kimberling WJ, Lynch JF, Cheng SC, Costello KA, Mulcahy GM, Wagner CA, Tindall SL. Genetic predisposition to breast cancer. Cancer 1984;53(Suppl):612-22.

6 Newman B, Austin MA, Lee M, King MC. Inheritance of human breast cancer evidence for autosomal dominant transmission in high risk families. Proc Natl Acad Sci USA 1988:85:3044-48.

7 Claus EB, Schildkraut JM, Thompson WD, Risch NJ. The genetic attributable risk of breast and ovarian cancer. Cancer 1996;772:318-24.

8 Hall JM, Lee MK, Newman B, Morrow JE, Anderson LA, Huey B, King MC. Linkage of early-onset familial breast cancer to chromosome 17q21. Science 1990;250:1684-89.

9 Miki Y, Swensen J, Shattuck-Eidens D, Futreal PA, Harshman K, Tavtigian S Liv Q, Cochran C, Bennett LM, Ding W, Bell R, Rosenthal J, Hussey C, Tran T, McClure M, Frye C, Hattier T, Phelps R, Haugen-Strano A, Katcher $\mathrm{H}$, Yakumo K, Glolaml Z, Shaffer D, Stones S, Bayar S, Wray C, Bogden R, Dayanath P, Ward J, Tortin P, Narod S, Bristow PK, Normmis FH, Helvering L, Morrison P, Rosteck P, Lai M, Barrett JC, Lewis C, Neuhausen S, CannonAlbright L, Goldgar D, Wiseman R, Kamb A, Skolnick MA. A strong candidate for the breast and ovarian cancer susceptibility gene BRCA1. Science 1994; 266:66-71.

10 Castilla LH, Couch FJ, Erdos MR, Hoskins KF, Calzone K, Garber JE, Boyd J, Lubin MB, Deshano ML, Brody LC, Collins FS, Weber BL. Mutations in the BRCA1 gene in families with early-onset breast and ovarian cancer. Nat Genet 1994;8:387-91.

11 Friedman LS, Ostermeyer EA, Szabo Cl, Dowd P, Lynch ED, Rowell SE, King MC. Confirmation of BRCA1 by analysis of germline mutations linked to breast and ovarian cancer in ten families. Nat Genet 1994;8:399-404

12 Couch FJ, Weber BL. Mutations and polymorphisms in the familial early-onset breast cancer (BRCA1) gene. Breast Cancer Information Core. Hum Mutat 1996:8:8-18.

13 Shattuck-Eidens D, Oliphant A, McClure M, McBride C, Gupte J, Rubano T, Pruss D, Tavtigian SV, Teng DH, Adey N, Staebell M, Gumpper K, Lundstrom R, Hulick M, Kelly M, Holmen J, Lingenfelter B, Manley S, Fuijimura F, Luce M, Ward B, Cannon-Albright L, Steele L, Offit K, Thomas A. BRCAl sequence analysis in women at high risk for susceptibility mutations. Risk factor analysis and implications for genetic testing. JAMA 1997; 278: 1242-50.

14 Breast Cancer Information Core Database. http://research.nhgri.nih.gov/ bic/.

15 Neuhausen SL. Ethnic differences in cancer risk resulting from genetic variation. Cancer 1999:86(Suppl):2575-82.

16 Gayther SA, Harrington P, Russell P, Kharkevich G, Garkavtseva RF, Ponder BA. Frequently occurring germ-line mutations of the BRCA 1 gene in ovarian cancer families from Russia. Am J Hum Genet 1997:60:1239-42.

17 Baudi F, Quaresima B, Grandinetti C, Cuda G, Faniello C, Tassone P, Barbieri V, Bisegna R, Ricevuto E, Conforti S, Viel A, Marchetti P, Ficorella C, Radice P, Costanzo F, Venuta S. Evidence of a founder mutation of BRCAl in a highly homogeneous population from Southern Italy with breast/ovarian cancer. Hum Mutat 2001:18:163-4.

18 Inoue R, Fukutomi T, Ushiijima T, Matsumoto Y, Sugimura T, Nagao M. Germline mutations of BRCA1 in Japanese breast cancer families. Cancer Res $1995 ; 55: 3521-24$.
19 Tang NL, Pang CP, Yeo W, Choy KW, Lam PK, Suen M, Law LK, King WW, Johnson P, Hielm M. Prevalence of mutations in BRCAl gene among Chinese patients with breast cancer. J Natl Cancer Inst 1999;91:882-85

20 Sng JH, Chang J, Feroze F, Rahman N, Tan W, Lim S, Lehnert M, van der Pool S, Wong J. The prevalence of BRCAl mutations in Chinese patients with early onset breast cancer and affected relatives. Brit J Cancer 2000;82:538-42.

21 Ikeda N, Miyoshi Y, Yoneda K, Shiba E, Sekihara Y, Kinoshita M, Noguchi S. Frequency of BRCA1 and BRCA2 germline mutations in Japanese breast cancer families. Int J Cancer 2001:91:83-88.

22 De Leon Matsuda ML, Liede A, Kwan E, Mapua CA, Cutiongco EM, Tan A, Borg A, Narod SA. BRCA1 and BRCA2 mutations among breast cancer patients from the Philippines. Int I Cancer 2002;98:596-603.

23 Kang HC, Kim IJ, Park JH, Kwon HJ, Won YJ, Heo SC, Lee SY, Kim KH, Shin Y, Noh DY, Yang DH, Choe KJ, Lee BH, King SB, Park JG. Germline mutations of $B R C A 1$ and BRCA2 in Korean breast and/or ovarian cancer families. Hum Mutat 2002;20:235.

24 Patmasiriwat P, Bhothisuwan K, Sinilnikova OM, Chopin S, Methakijvaroon S, Badzioch M, Padungsutt P, Vattanaviboon P, Vattanasapt V, Szabo C, Saunders GF, Goldgar D, Lenoir GM. Analysis of breast cancer susceptibility genes BRCA1 and BRCA2 in Thai familial and isolated early-onset breast and ovarian cancer. Hum Mutat 2002;20:230

25 Khoo US, Chan KY, Cheung AN, Xue WC, Shen DH, Fung KY, Ngan HY, Choy KW, Pang CP, Poon CS, Poon AY, Ozcelik H. Recurrent BRCAl and BRCA2 germline mutations in ovarian cancer: A founder mutation of BRCA1 identified in the Chinese population. Hum Mutat 2002;19:307-8.

26 Sambrook J, Fritsch E F, Maniatis T. Isolation of high molecular weight DNA from mammalian cells. New York: Cold Spring Harbor Laboratory Press, 1989:14-23.

27 Plummer SJ, Anton-Culver H, Webster L, Noble B, Liao S, Kennedy A, Belinson J, Casey G. Detection of BRCA1 mutations by the protein truncation test. Hum Mol Genet 1995;4:1989-91.

28 Hogervorst FB, Cornelis RS, Bout M, van Vliet M, Oosterwijk JC, Olmer R, Bakker B, Kliin JG, Vasen HF, Meijers-Heiiboer H, Meviko FH, Cornelisse CJ, den Dunnen JT, Devilee P, van Ommen G-JB. Rapid detection of BRCA1 mutations by the protein truncation test. Nat Genet 1996;10:208-12.

29 Szabo C, Masiello A, Ryan JF, Brody LC. The breast cancer information core: database design, structure, and scope. Hum Mutat 2000;16:123-31.

30 den Dunnen JT, Antonarakis SE. Mutation nomenclature extensions and suggestions to describe complex mutations: a discussion. Hum Mutat 2000;15:7-12

31 Anderson LA, Friedman L, Osborne-Lawrence S, Lynch E, Weissenbach J, Bowcock A, King MC. High-density map of the BRCAl region of Chromosome 17q12-q21. Genomics 1993;17:618-23.

32 Neuhausen SL, Swensen J, Miki Y, Liu Q, Tavtigian S, Shattuck-Eidens D, Kamb A, Hobbs MR, Gingrich J, Shizuya H, Kim UJ, Cochran C, Futreal PA, Wiseman RW, Lynch HT, Tonin P, Narod S, Cannon-Albringht L, Skolnick MH, Goldgar DE. A P1-based physical map of the region from DI7S776 to D17S78 containing the breast cancer susceptibility gene BRCA1. Hum Mol Genet 1994;3:1919-26.

$33 \mathrm{Ho}$ GH, Phang BH, Ng IS, Law HY, Soo KC, Ng EH. Novel germline BRCA mutations in women in Singapore who developed breast carcinoma before the age of 36 years. Cancer 2000;15:811-16.

34 Ford D, Easton DF, Bishop DT, Narod SA, Goldgar DE. Risks of cancer in BRCA1-mutation carriers. Breast Cancer Linkage Consortium. Lancet 1994;343:692-5

35 Easton DF, Ford D, Bishop DT. Breast and ovarian cancer incidence in BRCA1mutation carriers. Breast Cancer Linkage Consortium. Am J Hum Genet 1995;56:265-71

36 Struewing JP, Hartge P, Wacholder S, Baker SM, Berlin M, McAdams M, Timmerman MM, Brody LC, Tucker MA. The risk of cancer associated with specific mutations of BRCA1 and BRCA2 among Ashkenazi Jews. New Engl J Med 1997;336:1401-8.

37 Goggins M, Schutte M, Lu J, Moskaluk CA, Weinstein CL, Petersen GM, Yeo CJ, Jackson CE, Lynch HT, Hruban RH, Kern SE. Germline BRCA2 mutations in patients with apparently sporadic pancreatic carcinomas. Cancer Res 1996:56:5360-4

38 Fasouliotis SJ, Schenker JG. BRCA1 and BRCA2 gene mutations: decisionmaking dilemmas concerning testing and management. Obstet Gynecol Surv 2000:55:373-84

39 Bonn D. Prostate-cancer screening targets men with BRCA mutations. Lancet Oncol 2000;3:714

40 Naderi A, Couch FJ. BRCA2 and pancreatic cancer. Int J Gastrointest Cancer 2002;31:99-106.

41 Anglian Breast Cancer Study Group. Prevalence and penetrance of BRCA and BRCA2 mutations in a population-based series of breast cancer cases. Br J Cancer 2000;83:1301-8.

42 Balraj P, Khoo AS, Volpi L, Tan JA, Nair S, Abdullah H. Mutation analysis of the BRCAl gene in Malaysian breast cancer patients. Singapore Med J 2002:43:194-7.

43 Johannesdottir G, Gudmundsson J, Bergthorsson JT, Arason A, Agnarsson BA, Eiriksdottir G, Johannsson OT, Borg A, Ingvarsson S, Easton DF, Egilsson V, Barkardottir RB. High prevalence of the $999 \mathrm{del} 5$ mutation in icelandic breast and ovarian cancer patients. Cancer Res 1996:56:3663-5.

44 Thorlacius S, Sigurdsson S, Biarnadottir H, Olafsdottir G, Jonasson JG Tryggvadottir L, Tulinius H, Eyfiord JE. Study of a single BRCA2 mutation with high carrier frequency in a small population. Am J Hum Genet 1997:60:1079-84

45 Barkardottir RB, Sarantaus L, Arason A, Vehmanen P, Bendahl PO, Kainu T, Syrjakoski K, Krahe R, Huusko P, Pyrhonen S, Holli K, Kallioniemi OP, Egilsson V, Kere J, Nevanlinna H. Haplotype analysis in Icelandic and Finnish BRCA2 999 del5 breast cancer families. Eur I Hum Genet 2001 9.773-9. 